\title{
GABA Synapses Formed in vitro by Local Axon Collaterals of Nucleus Accumbens Neurons
}

\author{
Wei-Xing Shia and Stephen Rayport \\ Departments of Psychiatry and Anatomy and Cell Biology, and Center for Neurobiology and Behavior, Columbia \\ University, Department of Neuropathology, New York State Psychiatric Institute, New York, New York 10032
}

\begin{abstract}
GABAergic medium-spiny neuron axons not only form the principal projections of the nucleus accumbens (nAcc) but also branch locally in a dense network overlapping their own dendrites, suggesting that their recurrent synapses mediate the major information processing functions of the nAcc. We used postnatal nAcc cultures to study these synapses individually. In culture, as in the intact nAcc, medium-spiny neurons account for over $95 \%$ of the cells and are GABAergic. Strikingly, these neurons showed a spike afterhyperpolarization (AHP) that was largely blocked by the GABA antagonist bicuculline. The bicuculline-sensitive AHP occurred without or with latency, and met criteria for monosynapticity; consistent with this, dye fills showed the presence of recurrent axons and a low incidence of dye coupling. Blockade of $\mathrm{Ca}^{2+}$ influx eliminated this autaptic PSP, while TTX almost completely eliminated it, indicating that it is due to exocytic GABA release principally at axodendritic contacts. While blocking $\mathrm{GABA}_{B}$ receptors had no direct effect on the autaptic PSP, activating these receptors with baclofen produced presynaptic inhibition, as well as directly mediated hyperpolarization; together, these actions increased the signal-to-noise ratio in the cellular response to synaptic inputs. Bicuculline also increased the signal-to-noise ratio; in addition, it induced burst firing and depolarization inactivation. In contrast, the indirect GABA agonist flurazepam and the GABA uptake blocker nipecotic acid each enhanced autaptic PSPs. Since autapses formed in vitro appear to be functionally equivalent to synapses between neighboring mediumspiny neurons that receive similar inputs, these results bear on the function of intrinsic GABA synapses in the intact nAcc. Thus, intrinsic GABA synapses are likely to regulate the signal-to-noise ratio in nAcc information processing and may be important targets for the modulatory actions of endogenous neurotransmitters and drugs.
\end{abstract}

IKey words: nucleus accumbens, medium-spiny neuron, local axon collateral, autapse, GABA synapse, baclofen, limbic system, cell culture, signal-to-noise ratio]

\footnotetext{
Received Aug. 6, 1993; revised Dec. 13, 1993; accepted Jan. 27, 1994.

We thank Ariel Deutch, Gordon Shepherd, and David Sulzer for their comments on the manuscript, Amy MacDermott for advise on local perfusion, Geetha Rajendran, Anne Li, and Ling Lin for technical assistance, and Ciba-Geigy for CGP35348. This work was supported by NIH Grants MH00705 and MH44736 (S.R.)

Correspondence should be addressed to Dr. Stephen Rayport, Columbia University Department of Psychiatry, New York State Psychiatric Institute, 722 West 168th Street, Unit 62, New York, NY 10032.

"Present address: Department of Psychiatry, Yale University School of Medicine, 333 Cedar Street, SHM B-256, New Haven, CT 06510.
}

Copyright (C) 1994 Society for Neuroscience $0270-6474 / 94 / 144548-13 \$ 05.00 / 0$
The nucleus accumbens (nAcc) is the major component of the ventral striatal complex and is thought to serve in the integration of behavior in an analogous way to the striatum in the organization of movement (cf. Carlsson and Carlsson, 1990; Smith and Bolam, 1990; Schultz et al., 1992). The similarity in function is borne out by the close resemblance between these two divisions of the striatal complex - they share a similar cellular makeup, and receive their main excitatory input from cortical afferents and modulatory dopaminergic input from the ventral midbrain (cf. Gerfen, 1988; Totterdell and Smith, 1989; Smith and Bolam, 1990; Sesack and Pickel, 1992). The principal neurons of the striatal complex are GABAergic medium-spiny neurons that comprise over $95 \%$ of the total neuronal population (cf. Gerfen, 1988; Smith and Bolam, 1990). The axons of these cells form the projections of the $\mathrm{nAcc}$, as well as dense networks within the nAcc overlapping their own dendrites (Bishop et al., 1982; Chang and Kitai, 1985; Penny et al., 1988; Kawaguchi et al., 1989, 1990; O'Donnell and Grace, 1993). These local axon collaterals account for most of the GABA synapses in the striatal complex (Bolam et al., 1985; Pasik et al., 1988; cf. Gerfen, 1988; Smith and Bolam, 1990), suggesting that medium-spiny neurons mediate the main information processing functions of the $n A c c$ as well as conveying information to projection areas.

Consistent with these observations, local infusion of GABAactive agents in the nAcc produces potent behavioral effects (Kerwin et al., 1979; Kuruvilla and Uretsky, 1984; Morgenstern et al., 1984; Worms et al., 1987; Kafetzopoulos, 1988; Austin and Kalivas, 1989; Plaznik et al., 1990; Stefanski et al., 1990; Wong et al., 1991). However, the intricacy of the synaptic connections in vivo and the multiple sites of action of these agents (Kito et al., 1986; Kovalev and Hetey, 1987; Zetterström and Fillenz, 1990; Uchimura and North, 1991) makes discerning the function of these intrinsic nAcc GABA synapses difficult. Intra-nAcc stimulation usually evokes GABAergic synaptic potentials associated with glutamatergic as well as other excitatory components (Chang and Kitai, 1986; Higashi et al., 1989; Uchimura et al., 1989; Uchimura and North, 1991). Even though GABA-mediated components may be isolated pharmacologically, it has been difficult to distinguish the portion of the PSP due to activation of medium-spiny neurons, GABA interneurons, or GABA afferents. Indeed, GABA inputs from different sources to the same cell may have different actions (cf. Lacaille et al., 1987; Johnson et al., 1992; Sugita et al., 1992).

We have used postnatal cultures to examine GABA synapses formed by nAcc medium-spiny neurons and found that-unlike most central neurons grown in monolayer cultures-nearly all of these neurons make recurrent GABA connections or autapses (cf. van der Loos and Glaser, 1972). These autapses make pos- 

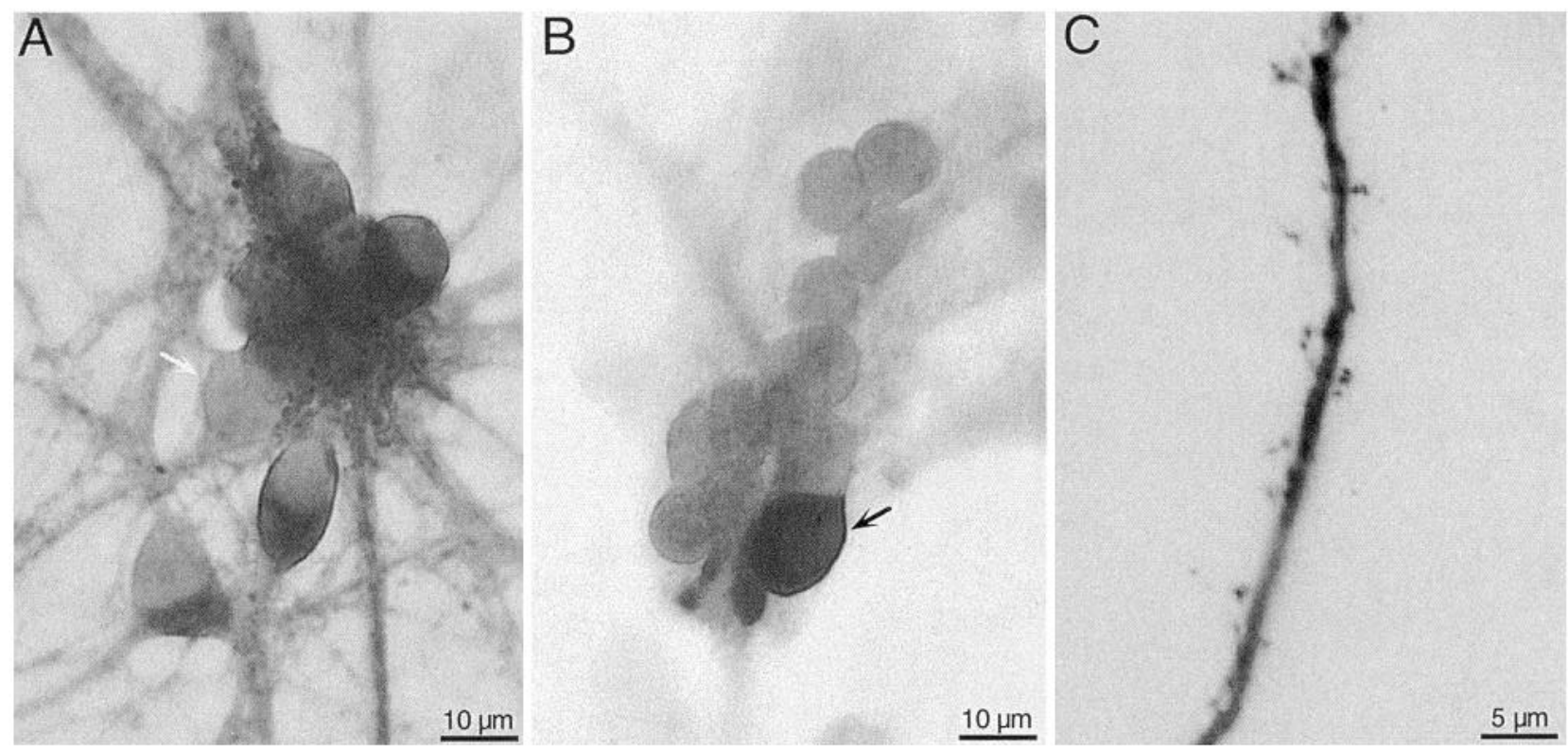

Figure 1. Identification of medium spiny nAcc neurons in vitro. A, nAcc neuron cultures are composed of a homogeneous population of mediumsized cells (10-15 $\mu \mathrm{m}$ in diameter), and a minority population of larger cells. As seen here, all but one of the neurons (white arrow) are GABAergic based on immunoreactivity for the GABA synthetic enzyme glutamic acid decarboxylase. Overall, over $95 \%$ of the medium-sized neurons are GABAergic. Note the intense staining of the neurites extending from the cell cluster. $B$, In a sister culture, only one neuron in a similar cluster stains for the acetylcholine synthetic enzyme choline acetyltransferase (black arrow). Overall, less than $5 \%$ of the cells, which tend to be larger (15$25 \mu \mathrm{m})$, are cholinergic. $C$, In an nAcc cell filled with sulforhodamine (10 $\mu \mathrm{M})$ (printed as a negative), the more distal dendrites are seen to be studded with spines.

sible the characterization of the properties of single intrinsic nAcc GABA synapses and their potential impact on nAcc information processing.

Portions of this work have been presented in abstract form (Shi and Rayport, 1992).

\section{Materials and Methods}

Cell culture. Postnatal nAcc cells were cultured following methods described previously for midbrain dopamine neurons (Rayport et al., 1992). Briefly, the brains of anesthetized P1-P11 Sprague-Dawley rat pups were placed in ice-cold phosphate-buffered saline, and the nAcc isolated following its borders, which, by postnatal life, largely resemble those in the adult (cf. Paxinos et al., 1991). To accomplish this, (1) the brain was cut coronally at the level of the hypothalamus, (2) the anterior brain was hemisected, (3) 2-mm-thick horizontal slices were cut at the level of the anterior commissure, (4) from each, a $2 \mathrm{~mm}$ coronal strip was cut just anterior to the anterior commissure at the midline, and (5) the nAcc, marked by the anterior tip of the lateral ventricle, was isolated by removing medial (olfactory tubercle) and lateral (striatum) parts of the strip. The resulting $2 \mathrm{~mm}^{3}$ tissue segment was cut into $1 \mathrm{~mm}$ cubes and dissociated using papain (Worthington; cf. Baughman et al., 1991). Cell suspensions were plated onto confluent cortical glia monolayers. Growth medium consisted of $47 \%$ MEM, $40 \%$ DME, $10 \%$ Ham's F- 12 , $4.5 \mathrm{mg} / \mathrm{ml}$ glucose, $0.25 \%$ albumin, $0.5 \mathrm{~mm}$ glutamine, $100 \mu \mathrm{g} / \mathrm{ml}$ transferrin, $15 \mu \mathrm{M}$ putrescine, $30 \mathrm{nM} \mathrm{Na}_{2} \mathrm{SeO}_{3}, 30 \mathrm{nM} \mathrm{T}_{3}, 25 \mu \mathrm{g} / \mathrm{ml}$ insulin, $200 \mathrm{~nm}$ progesterone, $125 \mathrm{~nm}$ cortisol, $5 \mu \mathrm{g} / \mathrm{ml}$ superoxide dismutase, $10 \mu \mathrm{g} / \mathrm{ml}$ catalase, $0.5 \mathrm{~mm}$ kynurenate (all from Sigma), and $1 \%$ supplemented-defined young calf serum (Hyclone). Proliferation of nonneuronal cells was suppressed with 5-fluorodeoxyuridine in uridine (Sigma) the following day. Cultures were then left undisturbed till recording.

Electrophysiology. Cells were visualized on an inverted microscope (Zeiss) with Hoffman modulation optics and continuously perfused with oxygenated extracellular solution containing $135 \mathrm{~mm} \mathrm{NaCl}, 3 \mathrm{~mm} \mathrm{KCl}$, $2 \mathrm{mM} \mathrm{CaCl}_{2}, 2 \mathrm{~mm} \mathrm{MgCl}, 10 \mathrm{~mm}$ glucose, and $10 \mathrm{~mm}$ HEPES, pH 7.4, at room temperature. Electrodes were fabricated from glass capillaries (o.d. $=1.5 \mathrm{~mm}$ ) using a P-80/PC Flaming-Brown Micropipette Puller (Sutter). The intracellular solution contained $140 \mathrm{~mm} \mathrm{~K}$-gluconate, 0.1 $\mathrm{mm} \mathrm{CaCl}_{2}, 2 \mathrm{~mm} \mathrm{MgCl}_{2}, 1$ mм EGTA, 2 mm ATP, 0.1 mм GTP, and
10 mM HEPES, pH 7.25; electrode resistance measured about $5 \mathrm{M} \Omega$. Following formation of a $\mathrm{G} \Omega$ seal, whole-cell mode was achieved with brief suction. Voltage and current signals were recorded using an Axopatch 200 interfaced to a 386 PC running pCLAMP (Axon). Off-line data analysis was performed in pCLAMP and Microsoft EXCEL using macros written by the authors to align spikes and do averaging. Numerical data are expressed as mean \pm SEM. Reported resting potentials include a tip potential correction of $25 \mathrm{mV}$.

Morphological analysis. The transmitter status of nAcc neurons was examined immunohistochemically using polyclonal antisera (Chemicon) to glutamic acid decarboxylase as a marker for GABA neurons and choline acetyltransferase as a marker for cholinergic neurons. The antisera were each used at a 1:5000 dilution and visualized with a Vectastain Elite kit and diaminobenzidine. To follow the elaboration of processes of individual medium-spiny GABA neurons, cells were filled with $0.1 \%$ Lucifer yellow (lithium salt) or 10-20 $\mu \mathrm{M}$ sulforhodamine by addition of the dyes to the intracellular solution. After completion of the electrophysiological examination of the cells, injected cells were visualized under fluorescein or rhodamine epifluorescence and images made with a chilled CCD camera (Photometrics Star 1); the resulting digital images were processed using NIH IMAGE 1.49 (Wayne Rasband).

Drugs. CGP35348 was generously provided by Ciba Geigy (Switzerland); baclofen, muscimol, bicuculline, saclofen, kynurenate, flurazepam, and nipecotic acid were obtained from Research Biochemicals Inc.; other agents were obtained from Sigma. All drugs were dissolved in the normal perfusate and applied through a U-tube local perfusion system (Oxford and Wagoner, 1989; Reichling and MacDermott, 1991) or puffers. For puffers, we used drug-filled pipettes with $5 \mu \mathrm{m}$ openings positioned 20-50 $\mu \mathrm{m}$ away from the recorded cell; drugs were ejected with controlled compressed air pulses of 5-10 psi for $0.1-1.0 \mathrm{sec}$ (Medical Systems).

\section{Results}

\section{Postnatal nAcc neurons in culture}

In postnatal nAcc cultures, the vast majority of neurons ( $>95 \%)$ formed a homogeneous population of medium-sized cells (10$15 \mu \mathrm{m}$ in diameter) (Fig. $1 A, B)$. These neurons were predominantly GABAergic by immunohistochemistry for glutamic acid 
Figure 2. Membrane properties of medium-sized nAcc cells to intracellular current injection. $A$, Action potentials triggered by depolarizing current pulses show a preceding slow depolarization and a large afterhyperpolarization (AHP). $B$, With longer current pulses, cells fire regularly. $C$, The current-firing relation for the cell shown in $B$ reveals a platcau in maximal firing rate. $D$, In another medium-sized cell, hyperpolarizing current injection reveals a time- and voltage-dependent inward rectification. $E_{l}$, In yet another medium-sized cell, TTX $(1 \mu \mathrm{g} / \mathrm{ml})$ abolishes both the slow depolarization and the fast action potential, suggesting that both are mediated by a TTX-sensitive $\mathrm{Na}^{+}$ current. $E_{2}$, During TTX, larger currents evoke a long-duration depolarization that is reversibly blocked by $\mathrm{Co}^{2+}(2 \mathrm{mM})$.

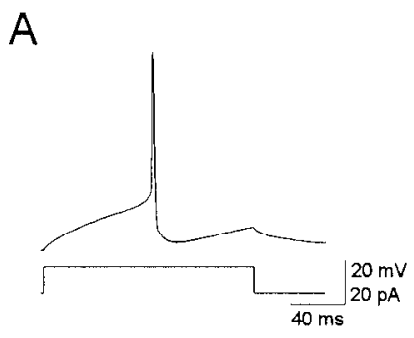

B

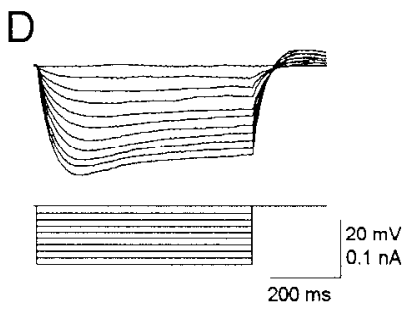

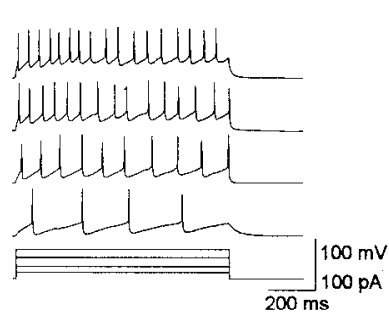

$E_{1}$

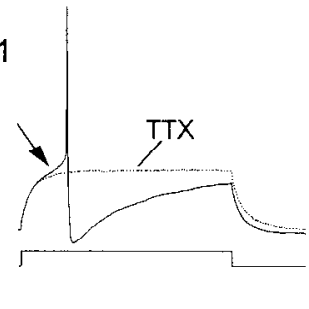

C
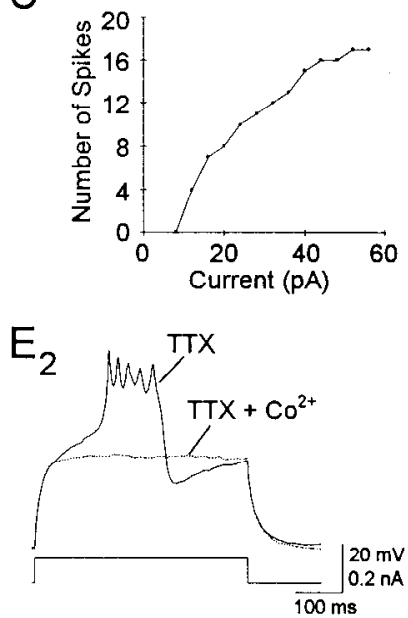

decarboxylase (GAD) (Fig. 1A). The minority of cells $(<5 \%)$ were somewhat larger $(15-25 \mu \mathrm{m}$ in diameter) and stained for choline acetyltransferase (CAT) (Fig. 1B). These percentages closely match the percentages of $\mathrm{GAD}^{+}$and $\mathrm{CAT}^{+}$cells in postnatal striatal cultures (Dubinsky, 1989). Ventral midbrain cultures run as controls showed about $75 \% \mathrm{GAD}^{+}$and $0 \% \mathrm{CAT}^{+}$ neurons, in line with the expected frequencies of these neurons in these cultures. When medium-sized cells were dye filled, spines were readily apparent on their more distal dendrites (Fig. 1C). These observations, together with their electrophysiological properties and synaptic physiology (see below), identify the medium-sized neurons as GABAergic medium-spiny neurons.

We made whole-cell recordings from 133 medium-sized nAcc neurons cultured for an average of $22 \mathrm{~d}$ (range 6-46 d). The resting membrane potential of these cells ranged from -76 to $-94 \mathrm{mV}$ (mean, $83.7 \pm 0.3, n-85$ ) and was stable throughout the recordings $(0.5-4 \mathrm{hr})$. As compared to the results of Dubinsky (1989) in postnatal striatal cultures, the higher resting potentials we observed are probably due to lower $\left[\mathrm{K}^{+}\right]_{o}$. Cells never fired spontaneously, though synaptic activity was occasionally observed. Input resistance determined by small hyperpolarizing pulses $(<10 \mathrm{mV})$ near resting membrane potential measured $1098 \perp 156 \mathrm{M} \Omega(n=25)$. Intracellular depolarizing current injection (Fig. $2 A$ ) or application of glutamate $(10-100 \mu \mathrm{M})$ evoked action potentials preceded by a slow depolarization. Action potential amplitude measured from rest was $100.2 \pm$ $1.2 \mathrm{mV}(n=84)$ with a duration of $2.7 \pm 0.1 \mathrm{msec}$ (measured at half amplitude; $n=84$ ). With long depolarizing current steps, cells fired repetitively and accommodated with strong depolarization (Fig. 2B,C). When cells were hyperpolarized, a timeand voltage-dependent membrane rectification was observed in $71 \%$ of cells $(n=14)$ (Fig. $2 D)$. TTX $(1 \mu \mathrm{g} / \mathrm{ml})$ reversibly blocked both the slow depolarization and the action potential (Fig. $2 E_{l}$ ). During TTX, larger depolarizing current steps evoked a depolarizing potential that was reversibly blocked with $\mathrm{Co}^{2+}$ (Fig. $2 E_{2}$ ), showing the presence of high-threshold $\mathrm{Ca}^{2+}$ spikes in these cells. In comparison to the slice (Uchimura et al., 1989; Pennartz and Kitai, 1991; Uchimura and North, 1991), nAcc cells in culture showed higher input resistances and broader spikes, which could be due to the lower recording temperature, different extra- and intracellular solutions (e.g., Church, 1992), whole-cell recording (Staley et al., 1992), or the absence of afferents in culture.

\section{Spike afterhyperpolarization}

In all the cells studied, action potentials were followed by an afterhyperpolarization (AHP). The duration and amplitude of the AHP increased with depolarization and reversed with hyperpolarization, showing a reversal potential of -75.5 to -95.3 $\mathrm{mV}(-86.8 \pm 2.0$, measured under voltage clamp; $n=9)$; both the duration and amplitude of the AHP diminished with repetitive firing. In $38 \%$ of cells $(n=84)$, an inflection in the falling phase of AHP was observed, suggesting that the AHP had more than one component (Fig. $3 A$, left; $C$ ). In these cells, the delayed AHP component exhibited a latency of $2.8-9.2 \mathrm{msec}$ $(4.9 \pm 0.3$, measured from the peak of the action potential to the start of inflection; $n=32$ ). For a given cell, this latency was fixed. The amplitudes of the delayed AHP component varied over a range from 2 to $33 \mathrm{mV}(13.3 \pm 1.4, n=32$, measured from the start of the inflection to the point of maximum AHP negativity).

The AHP was reversibly blocked by $\mathrm{Co}^{2+}(2 \mathrm{~mm})$ or $\mathrm{Cd}^{2+}$ $(0.1-0.2 \mathrm{~mm})$, consistent with mediation by $\mathrm{a} \mathrm{Ca}^{2+}$-dependent $\mathrm{K}^{+}$current. However, the delayed AHP component in some cells led us to suspect that it might be mediated by recurrent synaptic connections that would also be blocked by $\mathrm{Ca}^{2+}$ channel antagonists. To test this possibility, we used bicuculline $\left(\mathrm{GABA}_{\mathrm{A}}\right.$ antagonist, $1-100 \mu \mathrm{M}, n=80$ ), saclofen $\left(\mathrm{GABA}_{\mathrm{B}}\right.$ antagonist, $10-$ $200 \mu \mathrm{M}, n=6)$, CGP35348 (GABA ${ }_{\mathrm{B}}$ antagonist, $500 \mu \mathrm{M}, n=$ 4), or kynurenate (broad-spectrum glutamate antagonist, $1 \mathrm{mM}$, $n=4)$. Bicuculline dose-dependently attenuated and blocked the delayed AHP component in all cells tested (Fig. 3A,C), whereas the other agents were without effect (Fig. $3 B, C$ ). To our surprise, in nearly all the remaining cells that showed no inflection in the falling phase of AHP, bicuculline also attenuated the AHP (Fig. 3A, right). Overall, $95 \%$ of the cells tested ( $n=$ 80) showed bicuculline-sensitive AHP components.

In addition to its effect on the AHP, bicuculline also induced a small change in resting membrane potential in $33 \%$ of the cells examined ( 26 of 79 ). Among these, $58 \%$ showed a depo- 


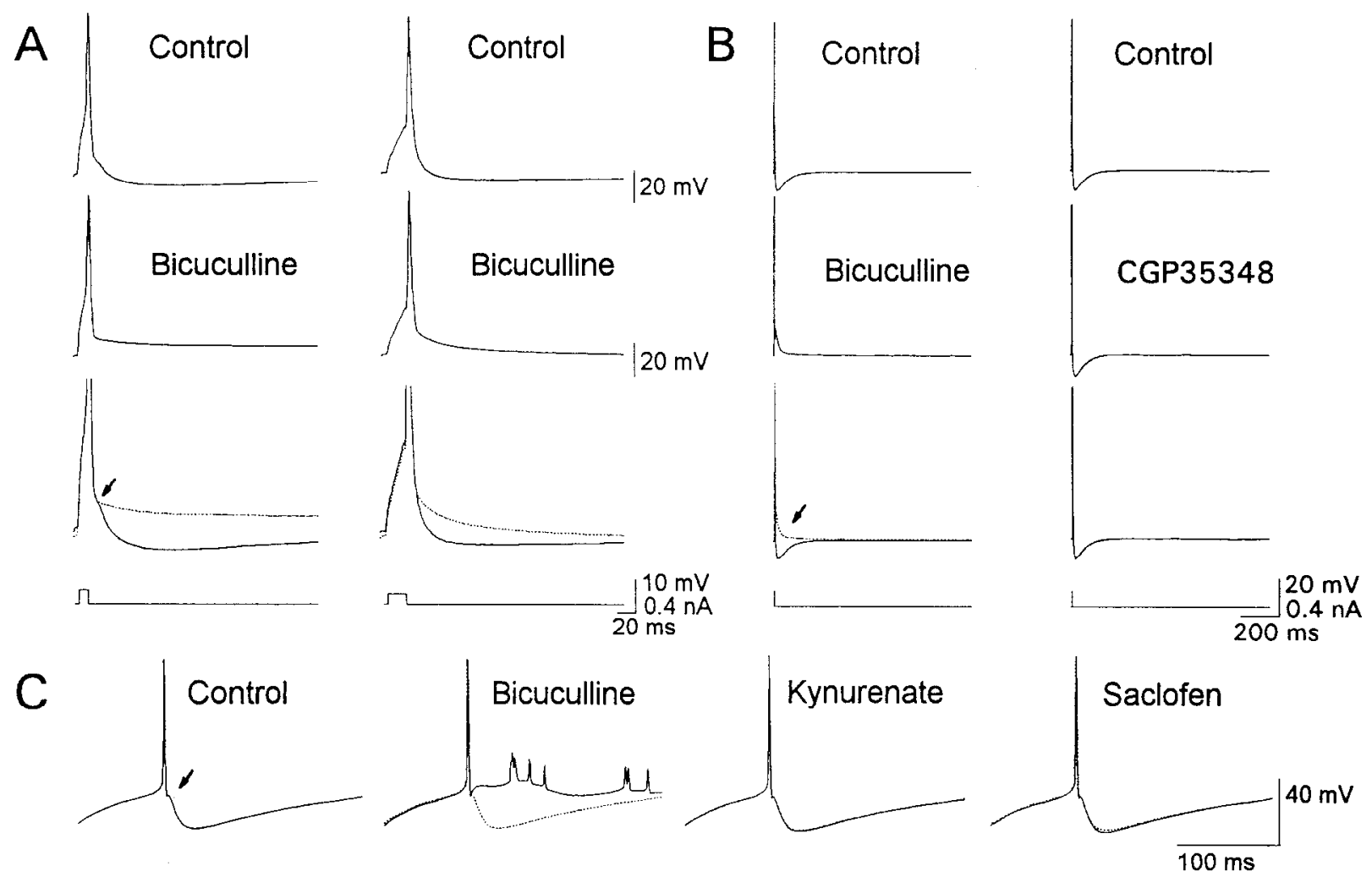

Figure 3. $\mathrm{GABA}_{\mathrm{A}}$-mediated AHP in nAcc cells. $A$, Examples of two types of AHPs in nAcc cells: one with an inflection in the falling phase of the AHP (arrow, also shown in another cell in $C$ ), and one without (top right). Both are blocked by the GABA antagonist bicuculline (50 $\mu \mathrm{M}$ and $20 \mu \mathrm{M}$, respectively; middle traces). Recordings before (solid trace) and during bicuculline (dotted trace) are superimposed and shown below at double amplitude (spike peaks are truncated). $B$, In another cell, bicuculline $(20 \mu \mathrm{M})$ blocks the AHP (arrow), while the GABA $\mathrm{B}_{\mathrm{B}}$ antagonist CGP35348 $(500 \mu \mathrm{M})$ has no effect. $C$, In another cell, the glutamate antagonist kynurenate $(1 \mathrm{mM})$ and the $\mathrm{GABA}_{\mathrm{B}}$ antagonist saclofen $(100 \mu \mathrm{M})$ are applied. Unlike bicuculline $(100 \mu \mathrm{M})$, which blocks the AHP, neither kynurenate nor saclofen has any significant effect. Dotted traces show the recordings under control conditions for comparison. Note the clear inflection in the AHP of this cell (arrow). Cells in this panel are stimulated with a current step beginning at the onset of the trace (not shown); each trace is the average of five recordings made after aligning the spikes; the small spikes during bicuculline are asynchronous action potentials reduced in apparent amplitude by averaging.

larization ( $1.8 \pm 0.3 \mathrm{mV}, n=15)$ and $42 \%$ showed a hyperpolarization $(-2.8 \pm 0.8 \mathrm{mV}, n=11)$. Since bicuculline attenuated the AHP without an effect on resting membrane potential in most cells, and similar degrees of depolarization or hyperpolarization induced by current injection did not block the AHP (data not shown), it is unlikely that blockade of the AHP resulted from changes in resting membrane potential.

\section{Origin of bicuculline-sensitive $A H P$}

The bicuculline-sensitive AHP was reliably evoked by action potentials in the recorded cell and occurred with a fixed latency (Fig. $4 A$ ), suggesting that it was monosynaptically mediated. To examine this further, we increased extracellular $\mathrm{Mg}^{2+}$ concentrations (4-15 $\mathrm{mm}, n=4)$ to raise spike threshold and thereby block activation of interneurons in a polysynaptic pathway. While elevated $\mathrm{Mg}^{2+}$ markedly increased spike threshold and decreased the size of spontaneous synaptic potentials (Fig. 4B), the bicuculline-sensitive AHP occurred with the same latency as under control conditions (Fig. $4 B$ ), strongly suggesting that the bicuculline-sensitive AHP is monosynaptically mediated and thus is due to autaptic GABA release.

To rule out the possibility that the recorded neuron made an electrical synapse on a GABA cell that synapsed back onto the recorded cell (although interneurons receiving electrical syn- apses would also be less likely to fire in elevated $\mathrm{Mg}^{2+}$ ), we filled cells with Lucifer yellow, which crosses gap junctions between striatal neurons (Cepeda et al., 1989). In 20 cells examined, there were two instances of dye coupling. In the remaining 18 cells, only the recorded cell was labeled; of these, 17 showed a bicuculline-sensitive AHP. Thus, the incidence of dye coupling - which was lower than in the slice (Cepeda et al., 1989)did not occur often enough to account for the observed frequency of bicuculline-sensitive AHPs.

Finally, if the bicuculline-sensitive AHP was indeed mediated by recurrent axon collaterals and was monosynaptic, one would expect to see close appositions between the axons of recorded cells and their dendrites. When examined at high magnification $(n=3)$, dye-filled cells with bicuculline-sensitive AHPs elaborated axons that made multiple contacts with the dendrites of the same cell (Fig. 5). Taken together, these lines of evidence support the idea that the bicuculline-sensitive AHP recorded in postnatal medium-sized nAcc neurons in culture is autaptically mediated.

\section{$\mathrm{Ca}^{2+}$ dependence of bicuculline-sensitive $\mathrm{AHP}$}

GABA can be released by two mechanisms, which have been described in striatal neurons: $\mathrm{Ca}^{2+}$-dependent vesicular release or $\mathrm{Ca}^{2+}$-independent reversal of uptake (Pin and Bockaert, 1989). 

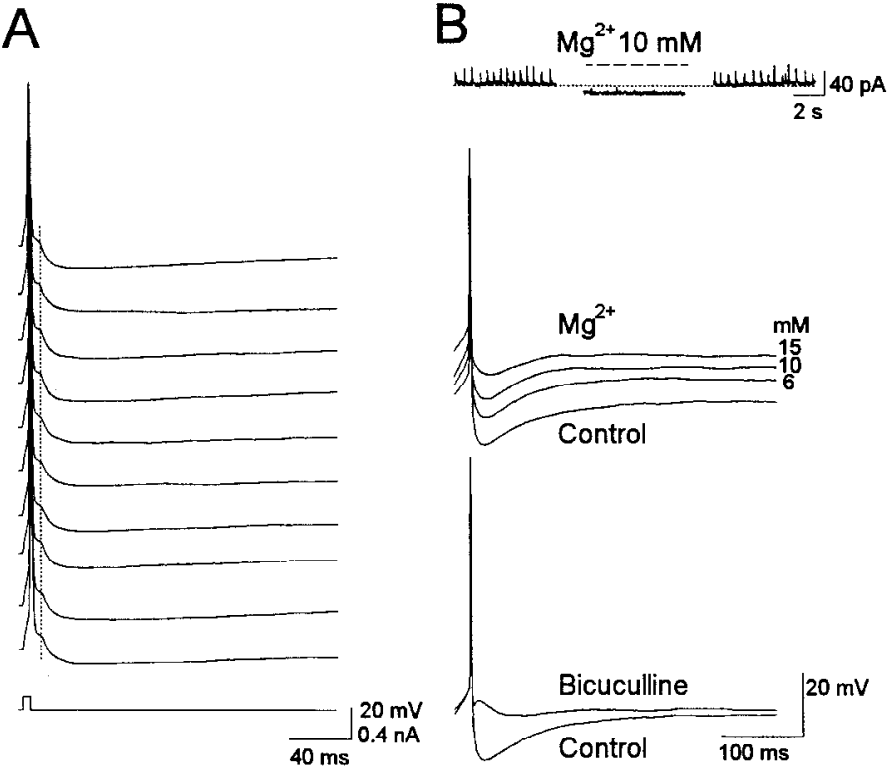

Figure 4. Monosynaptic properties of $\mathrm{GABA}_{\mathrm{A}}$-mediated AHP in $\mathrm{nAcc}$ cells. $A$, Ten consecutive recordings show that the $\mathrm{GABA}_{\mathrm{A}}$-mediated AHPs are reliably evoked by action potentials in the recorded cell and occur with a fixed latency (indicated by the vertical dotted line). $B$, Although high $\left[\mathrm{Mg}^{2+}\right]_{0}$ decreases the size of spontaneous synaptic potentials (top trace) and increases spike threshold, the bicuculline-sensitive AHP persists (middle traces), consistent with its being monosynaptic. The AHP is blocked by bicuculline $(50 \mu \mathrm{M})$ under control conditions (lower traces). The middle and lower traces in $B$ are each averages of five recordings.

To distinguish between the contribution of these mechanisms to the bicuculline-sensitive AHP, we perfused cells with zero $\mathrm{Ca}^{2+}, 4 \mathrm{~mm} \mathrm{Mg}^{2+}$ medium. Although cells still fired action potentials when depolarized, the bicuculline-sensitive AHP was completely blocked ( $n=5$; Fig. $6 \mathrm{~A}$ ). We ruled out the possibility that this was due to an altered response of the cell to released GABA by direct application of the $\mathrm{GABA}_{\mathrm{A}}$ agonist muscimol in control and in zero $\mathrm{Ca}^{2+}, 4 \mathrm{~mm} \mathrm{Mg}^{2+}$ medium. Puffs of muscimol (20-40 $\mu \mathrm{M})$ produced either an outward current under voltage clamp or a hyperpolarization under current clamp (Fig. $6 \mathrm{~B})$. The effect of muscimol was reversibly blocked by bicuculline $(20-100 \mu \mathrm{M})$ and persisted in the presence of TTX, consistent with a direct action mediated by $\mathrm{GABA}_{\mathrm{A}}$ receptors (Fig. $6 B$ ). In zero $\mathrm{Ca}^{21}, 4 \mathrm{~mm} \mathrm{Mg}^{2+}$ medium, the outward current induced by muscimol $(n=3)$ was either unchanged or slightly potentiated, while the bicuculline-sensitive AHP was completely blocked. Furthermore, rather than inhibiting the bicucullinesensitive AHP, which would be expected if it was mediated by reverse action of the GABA uptake transporter, the GABA uptake blocker nipecotic acid prolonged the bicuculline-sensitive AHP (see below).

We also examined the effects of $\mathrm{Co}^{2+}(2-4 \mathrm{mM}, n=6)$ and $\mathrm{Cd}^{2+}(100-200 \mu \mathrm{M}, n=3)$ on the bicuculline-sensitive AHP. Both $\mathrm{Ca}^{2+}$ antagonists inhibited the bicuculline-sensitive AHP; however, unlike zero $\mathrm{Ca}^{2+}, 4 \mathrm{mM} \mathrm{Mg}^{2+}$ medium, they also markedly attenuated muscimol-induced responses, consistent with an additional postsynaptic effect of these ions (Fig. 6B). Since zero $\mathrm{Ca}^{2+}, 4 \mathrm{~mm} \mathrm{Mg}^{2+}$ medium had no effect on muscimolinduced responses, reduction of $\mathrm{Ca}^{2+}$ influx into the postsynaptic neurons alone does not account for this effect of $\mathrm{Co}^{2+}$ or $\mathrm{Cd}^{2+}$.

\section{Short and long latency AHPS}

As described above, the bicuculline-sensitive AHP immediately followed spikes in the majority of cells, whereas in a minority, it occurred with a delay. Both kinds of AHPs met criteria for being autaptically mediated. What then accounts for the difference? In the AHPs with a delay, the constant latency and the sharp inflection at its onset strongly favor mediation by longer axon collaterals (see Discussion). AHPs without delays could be mediated by shorter axon collaterals with minimal conduction times or by somatodendritic GABA release. The zero $\mathrm{Ca}^{2+}$, $4 \mathrm{mM} \mathrm{Mg}^{2+}$ experiments (above) showed that the bicucullinesensitive AHP is $\mathrm{Ca}^{2+}$ dependent, arguing against $\mathrm{Ca}^{2+}$-independent somatodendritic release. To distinguish between axoand dendrodendritic synaptic $\mathrm{G} \wedge \mathrm{BA}$ release, we blocked action potential conduction with TTX and simulated somatic action potentials with a $4 \mathrm{msec}$ depolarization to $+40 \mathrm{mV}$. In three of six cells, TTX completely blocked the bicuculline-sensitive AHP, while in the other three cells, TTX blocked $>90 \%$ of the bicuculline-sensitive AHP, leaving a residual AHP with a slow onset and long duration (Fig. 7). Both nondelayed and delayed AIIPs were fully blocked by TTX, suggesting that differences in TTX sensitivity were not due to axo- as opposed to dendrodendritic release

\section{Functional impact of intrinsic $G A B A$ synapses on $n A c c$ information processing}

Since most intrinsic GABA synapses in the intact $n A c c$ are made by medium-spiny neurons onto neighboring medium-spiny neurons and inputs to the $n A c c$ are topographically organized, we propose that the functional impact of intrinsic nAcc GABA synapses may be examined using autapses as a model (see Discussion). To examine this, we compared the responses of $n A c c$ cells to pairs of short-duration current pulses, mimicking two consecutive synaptic inputs, prior to and during bicuculline. Although the two pulses were identical and the first one reliably evoked an action potential, the second pulse failed to do so when the interval between the pulses was less than $500 \mathrm{msec}$ (Fig. 8A). By attenuating the AHP, bicuculline significantly shortened the postspike inhibition period so that a spike could be triggered by the second pulse within as little as $200 \mathrm{msec}$. We examined this effect further in two experiments by comparing the frequency of stimulation to the frequency of evoked spikes (Fig. $8 B$ ). At low frequency $(1-2 \mathrm{~Hz}$ ), cells fired to each pulse. As the stimulation frequency was increased, the cells no longer faithfully translated each stimulation into a spike. In fact, the output frequency reached a maximum at $2 \mathrm{~Hz}$, despite input frequencies of $10 \mathrm{~Hz}$. Bicuculline extended the one-to-one input-output relation to about $10 \mathrm{~Hz}$.

The effects of GABA autapses on the responses of $n$ Acc cells can also be seen with depolarizing current pulses of different intensities. These GABA synapses had no effect on subthreshold stimulation-induced membranc responses (as they were not modified by bicuculline). As the stimulation intensity reached threshold, however, the response of the cell changed dramatically. Under control conditions, only a limited number of spikes could te evoked and the cell usually fired in a single-spike mode. In the absence of GABAergic inhibition (i.e., in the presence of bicuculline), the same depolarizing step evoked many more spikes and, in many cases $(n=18)$, a prolonged depolarization with a superimposed burst of spikes occurred (Fig. $8 \mathrm{C}$ ). In bicuculline, 


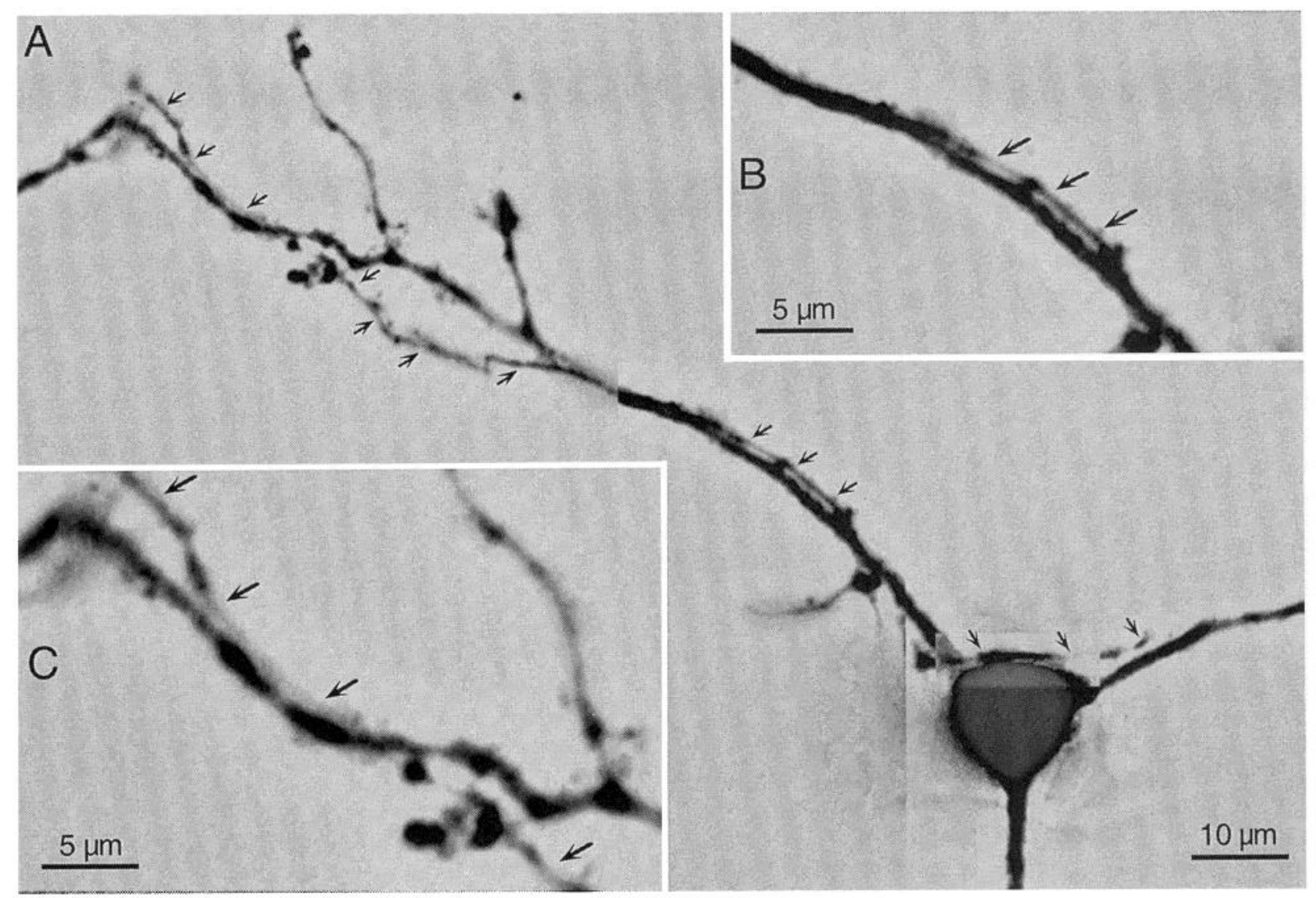

Figure 5. Visualization of recurrent collaterals of medium-spiny neurons. A, A nAcc cell with a large, delayed bicuculline-sensitive AHP was filled with sulforhodamine $(10 \mu \mathrm{M})$, and is shown in a photomontage of different focal planes (printed as a negative), revealing three main dendrites and one recurrent axon. The recurrent axon collateral contacts the cell body (three down-going arrows, lower right), then runs parallel to one dendrite (three down-going arrows, middle; enlarged twice in $B$ ), and intertwines with more distal dendritic processes (seven arrows, upper left; area identified by four downward-going arrows is enlarged twice in $C$ ). $B$, Unlike the dendrites, which are thicker, of tapering diameter, and end within a few hundred microns of the cell body, the axon is thinner, of uniform diameter, and extends over a thousand microns (not shown). $C$, Axon collaterals can be seen to come into repeated close apposition with dendritic branches.

when the depolarizing current step was further increased, cells often went into depolarization inactivation (see Fig. 11A).

\section{Modulation of input-output relations by baclofen and other GABA-active drugs}

To examine the possibility that intrinsic GABA synapses are an important site of action for transmitters and drugs that modulate information processing in the nAcc, we applied other GABA-active drugs, starting with the $\mathrm{GABA}_{\mathrm{B}}$ agonist baclofen. Baclofen (10-100 $\mu \mathrm{M})$ had a direct postsynaptic action seen in a hyperpolarization or outward current in $85 \%$ of the nAcc cells in culture $(n=20$; Figs. $9 A, 10 B)$. These effects were reversibly blocked by the $\mathrm{GABA}_{\mathrm{B}}$ antagonist CGP35348 $(500 \mu \mathrm{M}, n=3$; Fig. $9 B$ ). In the $15 \%$ of cells where no noticeable change in resting membrane potential or current occurred, baclofen still decreased cell excitability (Fig. 10A). In addition to its effect on resting membrane properties, baclofen (1-100 $\mu \mathrm{M})$ attenuated GABA PSPs (Fig. 9A). Since baclofen had no effect on muscimol responses (Fig. $9 \mathrm{C}$ ), this latter action of baclofen occurs via presynaptic inhibition.

The combined effects of baclofen on the excitability of the cell and on synaptic function dramatically changed the inputoutput relation. With small-amplitude input, baclofen suppressed output via its postsynaptic action of increasing spike threshold. As input became large enough to evoke multiple spikes, baclofen greatly enhanced the response of the cell by its presynaptic action (Fig. 9A). The modulatory effect of baclofen could be straightforwardly demonstrated with a ramp depolarization as shown in Figure $9 B$; initial spikes were delayed in baclofen (i.e., a stronger depolarization was needed to evoke a spike), while later spikes were more numerous.

We used this ramp depolarization to compare the effects of other agents on nAcc cells. As shown in Figure 11 $A$, bicuculline amplified the response of cells to suprathreshold stimulation by blocking GABAergic inhibition. However, this effect was not accompanied by a change in cell excitability, as seen in the constant latency of the first spike evoked. In addition, during bicuculline cells went into depolarization inactivation with higher levels of current injection, whereas the same cells continued to fire during baclofen at high frequency even with much higher current injections (Fig. 10B, same cell as shown in Fig. 11A). The benzodiazepine flurazepam $(10 \mu \mathrm{M})$ also had no effect on spike threshold, but decreased the response of cells to suprathreshold stimulation by potentiating the bicuculline-sensitive AHP (six of six cells; Fig. 11B). Similarly, the GABA uptake blocker nipecotic acid $(200 \mu \mathrm{M})$ potentiated the bicuculline-sensitive AHP and decreased suprathreshold stimulation-induced responses (three of four cells tested). However, in these same 
A
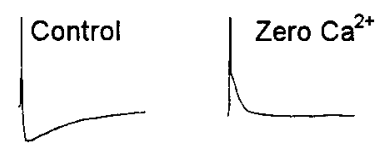

Bicuculline
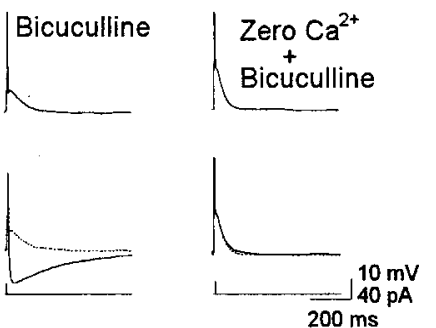

B
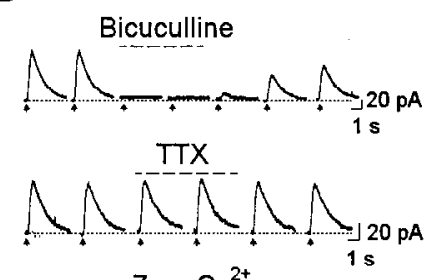

Zero $\mathrm{Ca}^{2+}$
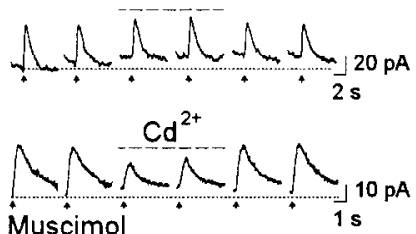

Figure 6. Autaptic GABA release is $\mathrm{Ca}^{2+}$ dependent. $A$, In this cell, an action potential triggers a large bicuculline-sensitive AHP; $100 \mu \mathrm{M}$ bicuculline blocks the autaptic potential (middle left and dotted line at bottom). Perfusion of zero $\mathrm{Ca}^{2+}$ medium produces a similar effect (top right), and the remaining AHP is not affected by bicuculline (middle right), suggesting that autaptic release is totally blocked by removal of $\mathrm{Ca}^{2+}$. Traces are averages of five recordings; spike peaks are truncated. $B$, Muscimol ( $40 \mu \mathrm{M}$, applicd in $0.5 \mathrm{sec}$ puffs starting at the arrows) produces an outward current, which is blocked by bicuculline (first row of traces) but not by TTX (second row). Zero $\mathrm{Ca}^{2+}$ medium has no effect on muscimol-induced outward current (third row), whereas $\mathrm{Cd}^{2+}(100$ $\mu_{\mathbf{M}}$ ) markedly attenuates it (fourth row).

cells, nipecotic acid also increased spike threshold (Fig. 11C); this was not mediated by a change in membrane potential, as nipecotic acid either had no effect or slightly depolarized cells.

\section{Discussion}

The present work shows that the AHP of postnatal mediumspiny nAcc cells in culture results mainly from the autaptic release of GABA acting at $\mathrm{GABA}_{\mathrm{A}}$ receptors. This is supported by the observations that the bicuculline-sensitive AHP (1) can be reliably evoked by the action potentials in the recorded cell with a short, fixed latency, (2) persists in high $\left[\mathrm{Mg}^{2+}\right]_{o}$, which blocks polysynaptic interactions, and (3) is present in cells that are not dye-coupled to other cells. Furthermore, single nAcc cells in microcultures (cf. Segal and Furshpan, 1990) also exhibit
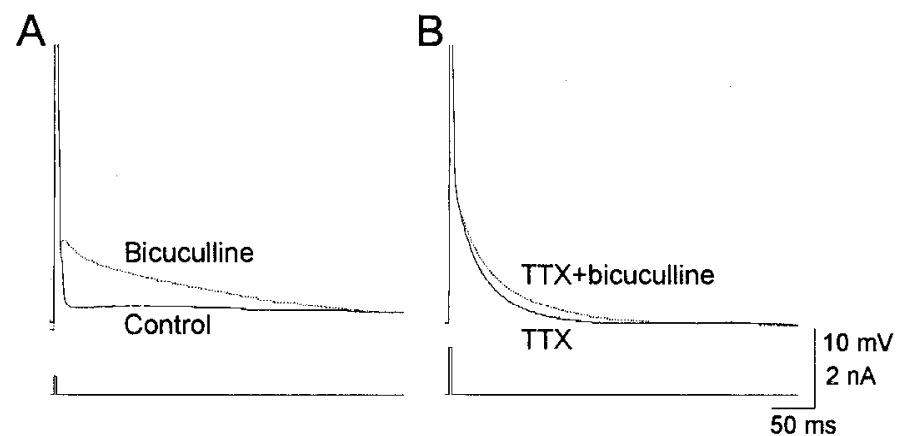

Figure 7. TTX-insensitive component of bicuculline-sensitive AHP in some cells. A, Under control conditions, a depolarizing current pulse triggers an action potential and a large AHP that is blocked by bicuculline $(50 \mu \mathrm{M}) . B$, In TTX $(1 \mu \mathrm{g} / \mathrm{ml})$, a brief depolarization $(4 \mathrm{msec}$, $+40 \mathrm{mV}$ ) to mimic an action potential evokes a small, slow $\mathrm{GABA}_{\mathrm{A}}$ mediated AHP. This is observed in about $50 \%$ of cells that had a bicuculline-sensitive AHP. Traces are averages of five recordings; spike peaks are truncated.
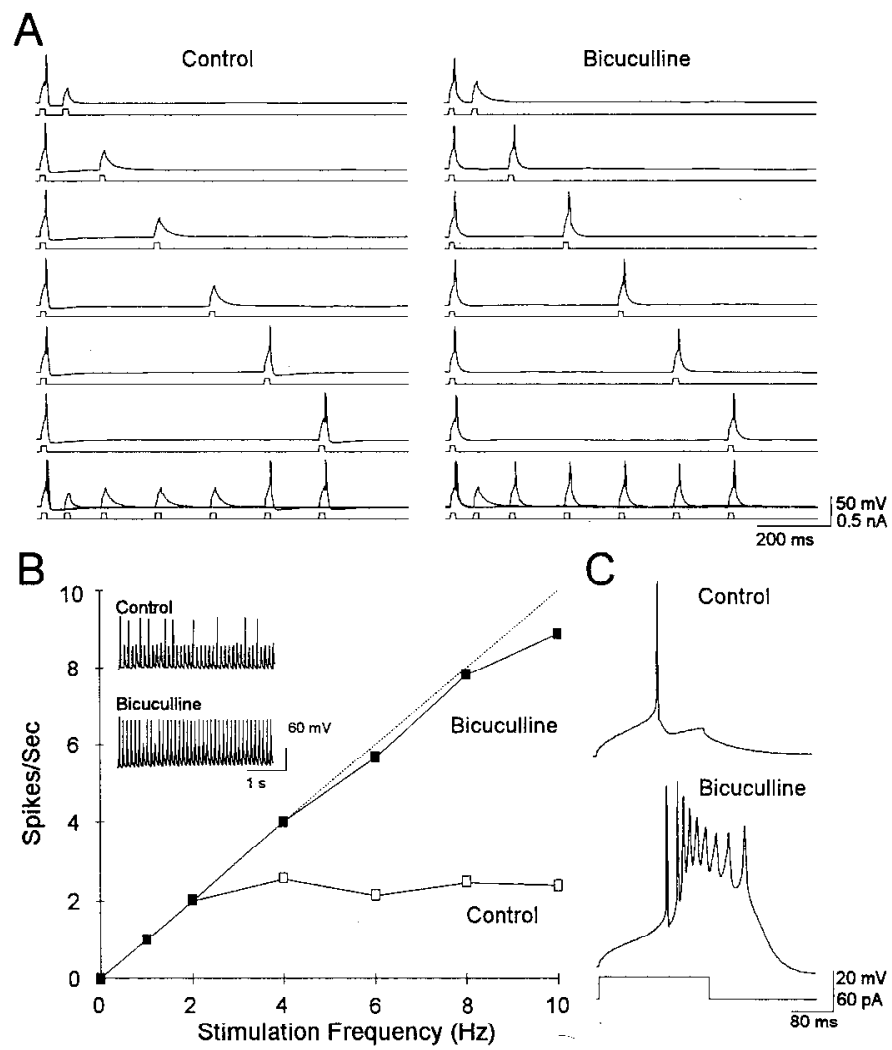

Figure 8. Autaptic modulation of the input-output relations of nAcc cells. $A$, When an nAcc cell is stimulated with a pair of current pulses of sufficient amplitude that the first pulse is suprathreshold, the second pulse fails to trigger a spike it if is applied within $550 \mathrm{msec}$. In bicuculline $(50 \mu \mathrm{M})$, the second pulse triggers a spike within $200 \mathrm{msec}$. $B$, This frequency-limiting action of the bicuculline-sensitive AHP strongly affects the input-output relation. In this cell, repetitive current pulses are applied at increasing frequency. At low frequency $(<2 \mathrm{~Hz})$, each input triggers a spike, while above $2 \mathrm{~Hz}$, the output of the cell shows no increase in firing rate. Bicuculline $(50 \mu \mathrm{M})$ extends the linear inputoutput relation to about $10 \mathrm{~Hz}$. The inset shows recordings during 10 $\mathrm{Hz}$ stimulation before and after bicuculline. $C$, Bicuculline can also induce burst firing. Under control conditions, a depolarizing current pulse evokes only a single spike followed by a large AHP (top trace), while $50 \mu \mathrm{M}$ bicuculline (bottom trace) blocks the AHP (not shown), resulting in a prolonged depolarization that triggers a burst of spikes.

$\mathrm{GABA}_{\mathrm{A}}$-mediated AHPs (W.-X. Shi, unpublished observations). The reliable presence of $\mathrm{GABA}$ autapses in nAcc culture provides a model system to examine individual intrinsic GABA synapses. While evoked PSPs in intact preparations include inputs from several classes of synapses, autaptic PSPs are mediated by a single class of synapses, just those of the recorded cell. Furthermore, pharmacological characterization of autapses immediately identifies the transmitter status of both presynaptic and postsynaptic elements. Since GABA synapses between medium-spiny neurons, like autapses, are also formed by axon collaterals synapsing on medium-spiny neurons, medium-spiny neuron autapses likely model the principal intrinsic GABA synapses of the nAcc.

\section{Mechanism of bicuculline-sensitive AHPS}

In striatal cell culture, the majority of $\mathrm{GABA}$ release arises from $\mathrm{Ca}^{2+}$-dependent exocytic release and the minority from $\mathrm{Ca}^{2+}$ independent reversal of uptake (Pin and Bockaert, 1989). The fact that bicuculline-sensitive AHPs are completely blocked by 


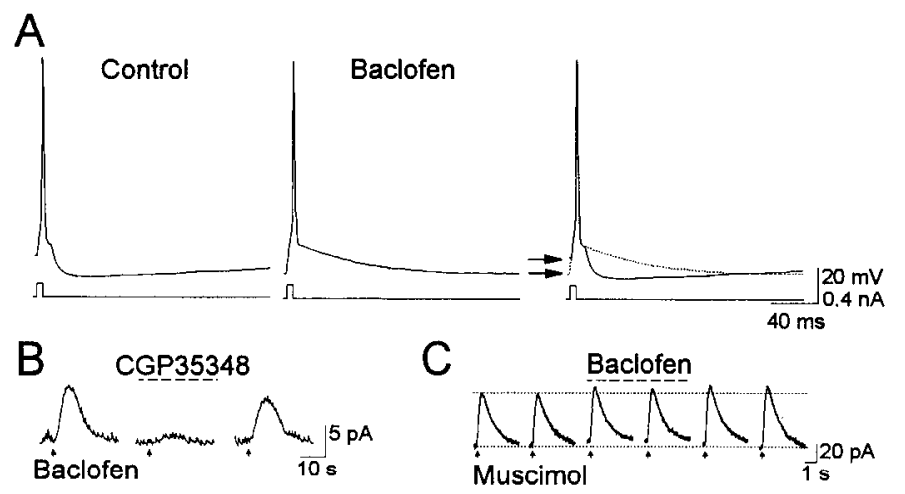

Figure 9. Presynaptic action of baclofen. A, Baclofen $(100 \mu \mathrm{M})$ blocks the bicuculline-sensitive AHP; in addition, it produces a membrane hyperpolarization (compare left and middle traces, superimposed on right; arrows shows two resting membrane potentials). Traces are averages of five recordings. $B$, Under voltage-clamp, baclofen $(100 \mu \mathrm{M}, 4$ sec puffs starting at arrows) induces an outward current that is reversibly blocked by concomitant application of the $\mathrm{GABA}_{\mathrm{B}}$ antagonist CGP35348 $(500 \mu \mathrm{M})$. C, Baclofen $(100 \mu \mathrm{M})$ shows no effect on muscimol $(40 \mu \mathrm{M}$, $0.5 \mathrm{sec}$ puffs) outward currents, suggesting that baclofen presynaptically inhibits autaptic PSPs.

impeding $\mathrm{Ca}^{2}$ । influx argues against a role for reversal of GABA uptake. Moreover, we have shown that the GABA uptake blocker nipecotic acid augments the bicuculline-sensitive AHP rather than attenuating it.

$\mathrm{Ca}^{2+}$-dependent AHPs could occur via axo- or dendrodendritic autaptic transmission. One supposition might be that the delayed bicuculline-sensitive AHP components are mediated by axodendritic autapses and those without delay by dendrodendritic autapses. However, this appears unlikely for the followings reasons. The large amplitude of autaptic as compared to synaptic potentials arising from activation of single GABAergic neurons in more intact preparations (cf. Miles, 1990) implies that autaptic potentials likely involve multiple release events at several active zones. This is consistent with our dye fills showing several sites of axodendritic interaction. The lack of multiple components in bicuculline-sensitive AHPs, their fixed latency, and sharp onset imply that these multiple release events are nearly simultaneous. This can best be explained by conduction times in axon collaterals extending over some distance before they branch relatively near their terminals.

AHPs without delay could be mediated by shorter axon collaterals or dendrodendritic interactions. To distinguish between these possibilities, we used TTX to block $\mathrm{Na}^{+}$-dependent regenerative activity and mimicked the somatodendritic action potential with a sharp depolarizing pulse. Passive electrotonic spread of such a pulse would be expected to activate proximal dendritic release sites (if they exist) but fail to reach all but the closest axonal sites. We found that TTX blocked the bicucullinesensitive AHP in half of the cells examined, arguing in favor of axonal mediation. In the other half of the cells where TTX was not completely effective, the residual bicuculline-sensitive AHP was both too small and too slow to contribute significantly to the nondelayed bicuculline-sensitive AHP. Furthermore, cells with delayed AHPs also showed this residual, TTX-insensitive component of the bicuculline-sensitive AHP, arguing that it arose by a mechanism distinct from axodendritic release. $\mathrm{Fi}$ nally, bicuculline-sensitive AHPs without delays also never showed multiple components, arguing that dendritic action potentials with their multiple components (cf. Regehr et al., 1993)
A
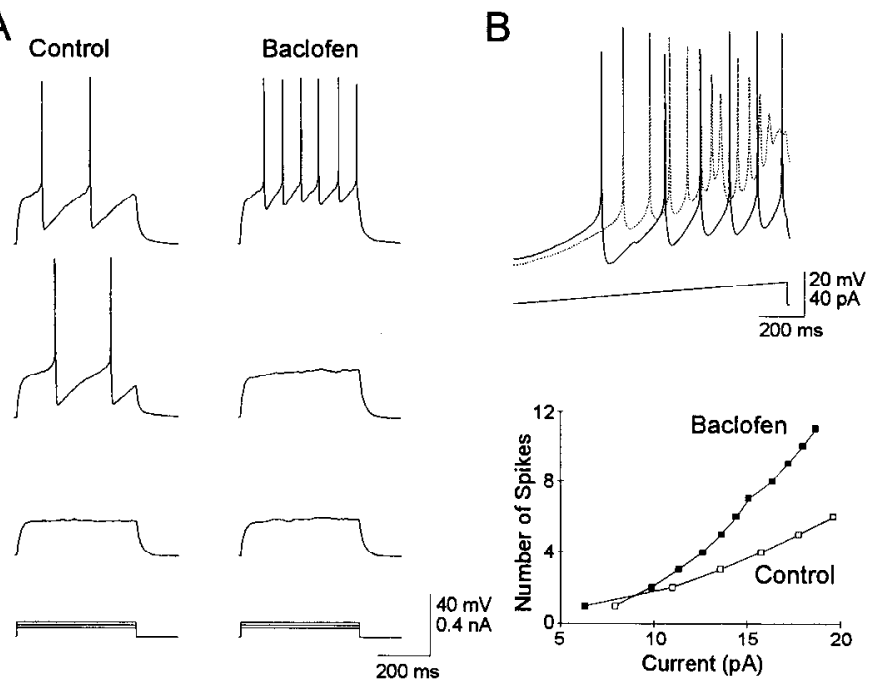

Figure 10. Effects of baclofen on input-output relations of $\mathrm{nAcc}$ cells. $A$, An nAcc cell is stimulated with increasing levels of depolarizing current. Baclofen $(100 \mu \mathrm{M})$ increases spike threshold so that the same stimulation that triggers two spikes under control conditions (middle left) is ineffective during baclofen (middle right). Baclofen also attenuates the autaptic potential and significantly shortens the interspike interval when spikes are evoked, so that when a larger current is applied, two spikes are evoked under control conditions (top left), while during baclofen six spikes are evoked (top right). The cell shown is one of a few cells in which baclofen did not affect the resting potential. $B$, In another cell, a ramp depolarization is used to elicit both the sub- and suprathreshold stimulation-induced responses. Baclofen $(100 \mu \mathrm{M}$, dotted trace $)$ suppresses the response of the cell to sub- or near-threshold stimulation (seen in the delayed appearance of the first spike during baclofen) and, at the same time, increases the resionse of the cell to suprathreshold stimulation (see as more spikes at higher current during baclofen). The differential effects of baclofen on sub- and suprathreshold stimulationinduced responses are seen clearly in a plot of spike number versus stimulation current.

do not contribute significantly to autaptic PSPs. Thus, both delayed and nondelayed bicuculline-sensitive AHPs are likely to be mediated by recurrent axon collaterals; in addition, there may be a minor component of autaptic exocytic release from dendritic sites.

\section{Localization of $G A B A$ receptors on medium-spiny neurons in culture}

In agreement with brain slice results (Uchimura and North, 1991), we find that medium-spiny $\mathrm{nAcc}$ neurons express both $\mathrm{GABA}_{\mathrm{A}}$ and $\mathrm{GABA}_{\mathrm{B}}$ receptors, as demonstrated by responses to muscimol and to baclofen. Autaptic potentials are solely $G A-$ $\mathrm{BA}_{\mathrm{A}}$ mediated, while $\mathrm{GABA}_{\mathrm{B}}$ receptors mediate presynaptic inhibition and somatodendritic hyperpolarization. Thus, both $\mathrm{GABA}_{\mathrm{A}}$ and $\mathrm{GABA}_{13}$ receptors appear to be nonuniformly distributed on $n A c c$ cells in culture. In particular, $\mathrm{GABA}_{\mathrm{A}}$ receptors appear to show preferential localization to postsynaptic sites and $\mathrm{GABA}_{\mathrm{B}}$ receptors to presynaptic terminals. While $\mathrm{GABA}_{\mathrm{B}}$ receptors appear also to be present on somatodendritic membranes, they are either diffusely distributed at low density or actively excluded from postsynaptic sites. These results are consistent with subcellular localization studies of $\mathrm{GABA}_{\mathrm{A}}$ receptors in the intact cerebellum (Somogyi et al., 1989) and in cultured cerebellar (Caruncho et al., 1993), hypothalamic (Ventimiglia et al., 1990), or cortical (Frosch and Dichter, 1992) neurons showing that $\mathrm{GABA}_{\mathrm{A}}$ receptors are differentially distributed on 
Figure 11. Modulation of the inputoutput relation of nAcc cells by other GABA-active agents. $A$, Bicuculline (50 $\mu_{\mathrm{M}}$, dotted trace), applied to the same cell as shown in Figure $9 B$, significantly enhances the response of the cell to strong stimulation without an effect on spike threshold. Different from baclofen, the same ramp depolarization in bicuculline drives the cell into depolarization inactivation. Both the raw data and spike number versus current plots are shown below for cach drug testcd. $B$, In another cell, the benzodiazepine flurazepam ( $10 \mu \mathbf{M}$, dotted trace) potentiates the AHP and markedly reduces the response to suprathreshold stimulation. $C$, In another cell, the GABA uptake blocker nipecotic acid $(200 \mu \mathrm{M}$, dotted trace) attenuates the response to suprathreshold stimulation. At the same time, however, it also suppresses the response to low-intensity stimulation (seen in the delayed appearance of the first spike).
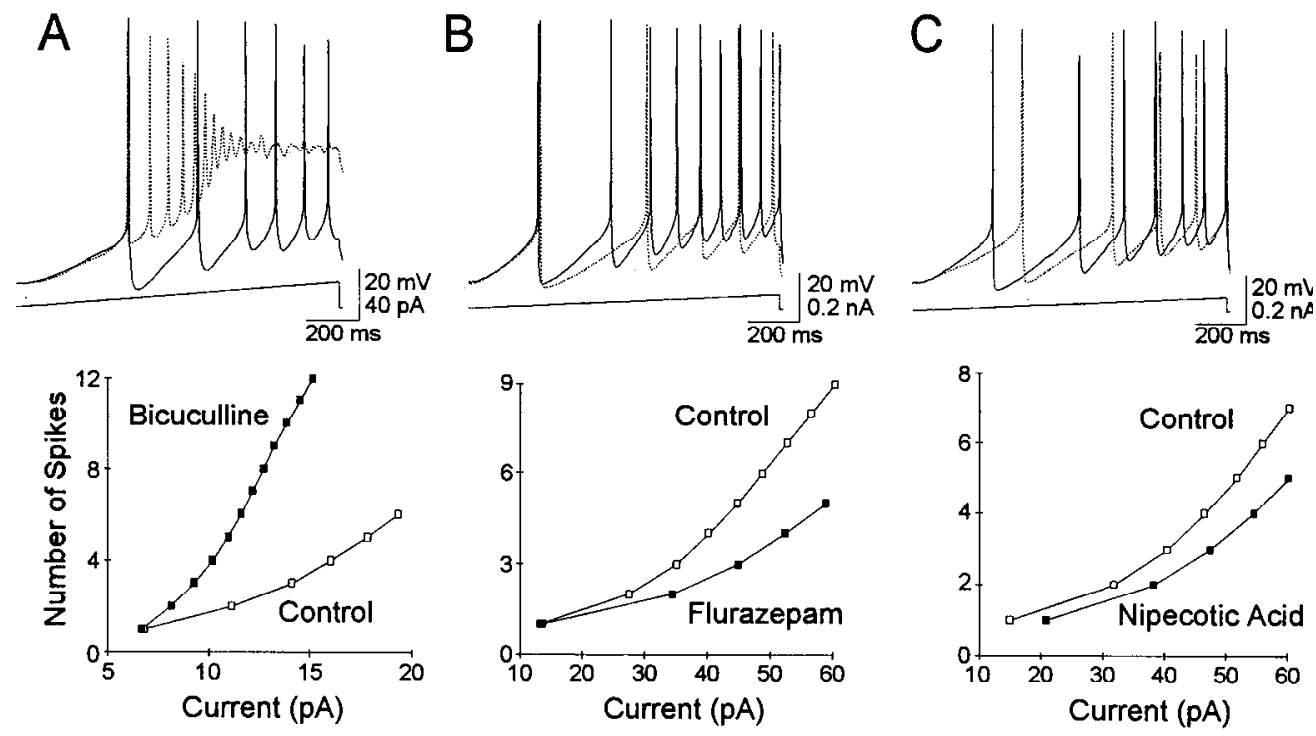

central neurons and usually clustered at postsynaptic sites. Similar studies of $\mathrm{GABA}_{\mathrm{B}}$ receptor distribution have yet to be done.

\section{Synaptic role of $G A B A_{B}$ receptors}

It is possible that while $\mathrm{GABA}_{\mathrm{A}}$ receptors are preferentially associated with the synapses formed by local axon collaterals, postsynaptic $\mathrm{GABA}_{B}$ receptors are localized to synapses formed by inputs from GABA interneurons or GABA afferents to the nAcc. We assume that medium-spiny to medium-spiny synapses have the same properties, regardless of whether the preand postsynaptic elements originate from the same or different medium-spiny neurons. Indeed, in postnatal striatal cultures, medium-spiny to medium-spiny inhibitory connections are ex-

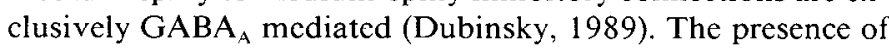
different GABA receptor subtypes on the same cell that are activated by different inputs has been reported in the amygdala (Sugita et al., 1992), ventral tegmental area (Johnson et al., 1992; Sugita et al., 1992), and hippocampus (Lacaille et al., 1987). In hippocampal microcultures, GABA PSPs in excitatory cells show both $\mathrm{GABA}_{\mathrm{A}}$ and $\mathrm{GABA}_{\mathrm{B}}$ components (Segal and Furshpan, 1990; Segal, 1991), while GABA PSPs in inhibitory cells show only the $\mathrm{GABA}_{\mathrm{A}}$ component (M. M. Segal, personal communication). Together with our observations, this suggests that even though GABA neurons express $G_{A B A}$ receptors, GABA inputs to these cells interact preferentially with $\mathrm{GABA}_{\mathrm{A}}$ receptors. This would argue against the likelihood of synapses onto presynaptic terminals of medium-spiny neurons mediated by $\mathrm{GABA}_{\mathrm{B}}$ receptors.

Possibly, in the intact $n A c c, G A B A_{B}$ receptors are activated by ambient $\mathrm{G} \Lambda \mathrm{B} \Lambda$ and do not participate directly in synaptic transmission. This is consistent with the observation that GABA PSPs evoked by intra-nAcc stimulation (during glutamate receptor blockade) that should activate all GABA inputs are blocked completely by bicuculline (Uchimura and North, 1991). Several brain slice studies show that baclofen inhibits intranAcc stimulation-evoked PSPs mediated by GABA as well as by glutamate (Calabresi et al., 199 1; Uchimura and North, 1991; Nisenbaum et al., 1992), consistent with a more general modulatory role. Unlike in culture where ambient GABA levels appear to be quite low (as evidenced by the usual lack of a

bicuculline effect on resting membrane potential), in the intact brain ambient GABA levels, which are significant (Campbell et al., 1993), are likely to exert a continuous modulation of GABA release via $\mathrm{GABA}_{\mathrm{B}}$ receptors. Additionally, higher-frequency activation of GABA synapses could be self-limiting, due to action of synaptically released GABA on presynaptic $G_{A B A}$ receptors, as has been observed in the hippocampus (Davies et al., 1990; Isaacson et al., 1993).

\section{Intrinsic GABA synapses and nAcc neural circuitry}

Most GABA synapses in the nAcc arise from recurrent collaterals of medium-spiny neurons (cf. Groves, 1983; Gerfen, 1988; Smith and Bolam, 1990) and are likely to play an important rolc in nAcc information proccssing. Based on the overlapping axonal pattern restricted to the dendritic field of the parent cell (Bishop et al., 1982; Penny et al., 1988; Kawaguchi et al., 1989, 1990; O'Donnell and Grace, 1993), the majority of mediumspiny neurons likely project to immediately neighboring medium-spiny cells and mediate a lateral inhibition important in spatial and temporal filtering of afferent input (Groves, 1983).

Several earlier studies in the intact brain and in the slice had suggested that the GABAergic medium-spiny neurons of the striatum make autaptic connections (Park et al., 1980; Preston et al., 1980; Katayama et al., 1981; Lighthall and Kitai, 1983). More recently, however, this has been refuted both functionally (Pennartz and Kitai, 1991) and morphologically (O'Donnell and Grace, 1993). However, if recurrent axons fasiculate with the dendrites of the parent cell in the intact nAcc as they do in culture, serial ultrastructural examination of individually labeled cells would be required to rule out autaptic interactions definitively. In any case, what is striking is that unlike most mammalian neurons in monolayer cultures, nAcc medium-spiny neurons almost invariably form autapses. This also appears to be the case for striatal neurons in culture where the AHP increases in size with a time course paralleling the development of inhibitory synaptic connections (Dubinsky, 1989). In contrast, ventral tegmental area dopamine neuron axons in culture tend to avoid the dendrites of the cell of origin and instead project radially over considerable distances (Rayport et al., 1992; S. Rayport, unpublished observations), and hippocampal glu- 
tamatergic neurons only make autapses when constrained in microcultures (Segal and Furshpan, 1990; Bekkers and Stevens, 1991). So, while the current evidence suggests that mediumspiny neurons do not form autapses in vivo, the propensity with which they do so in culture suggests that medium-spiny neurons might form autapses under pathological conditions where the cells are deprived of their normal targets as they are in culture.

Whether medium-spiny neurons feed back only onto their neighbors or onto themselves as well may not be functionally consequential because of the topographic organization of cortical and midbrain projections (Groves, 1983; Smith and Bolam, 1990). Neighboring medium-spiny neurons likely receive similar afferent input, so excitatory afferents would be expected to activate neighboring cells and their axon collaterals, leading to similar patterns of recurrent inhibition. Therefore, GABA synapses between the adjacent cells would be functionally equivalent to autapses (Fig. 12), and the information we have gleaned from autapses is likely to generalize to GABA synapses formed by neighboring medium-spiny neurons receiving similar synaptic input.

\section{Possible roles of recurrent synapses in $n A c c$ information processing}

Recurrent GABA synapses may modulate the response of medium-spiny neurons to input of different frequencies and intensities. In culture, autapses act as low-pass filters to inhibit responses to high-frequency stimulation. This function of autapses was initially described in Aplysia (White and Gardner, 1981). As they are only active when cells fire, autapses do not affect subthreshold stimulation-induced membrane responses or spike threshold, while they potently influence responses to suprathreshold stimulation. The removal of recurrent inhibition with bicuculline leads to stronger responses to given synaptic inputs as well as to bursting, which is never seen under control conditions, even with much stronger stimulation. Although the functional significance of burst firing in nAcc cells is unknown, studies in other preparations suggest that bursting increases transmitter release (Bloom et al., 1987; Gonon, 1988; SuaudChagny et al., 1992) and may favor cotransmitter release (Lundberg et al., 1986; Whim and Lloyd, 1989).

Additionally, when recurrent GABA synapses are blocked with bicuculline, stronger stimulation may drive cells into depolarization inactivation, so a further role of recurrent GABA synapses may be to prevent depolarization inactivation. In the intact brain (cf. Campbell et al., 1993), where ambient GABA levels are likely much higher (in culture most of the time bicuculline has no effect on resting membrane potential), bicuculline could also exert similar effects on medium-spiny neuron activity by disinhibition of dendritic $\mathrm{Ca}^{2+}$ spikes.

As previously suggested by van der Loos and Glaser (1972), it is likely that local axon collaterals synapse on only a subset of dendrites, leading to selective shunting of synaptic inputs. Indeed, Park et al. (1980) have shown that in the striatum, recurrent synapses selectively inhibit the input from the substantia nigra but not from the cortex. If so, cortical inputs could take over control of cell firing by activating intrinsic GABA synapses on dendrites receiving competing nigral input.

Modulation of nAcc information processing by agents acting at intrinsic nAcc GABA synapses

Our data demonstrate that intrinsic nAcc GABA synapses may be finely tuned by several GABA-active agents. Thus, bicucul-
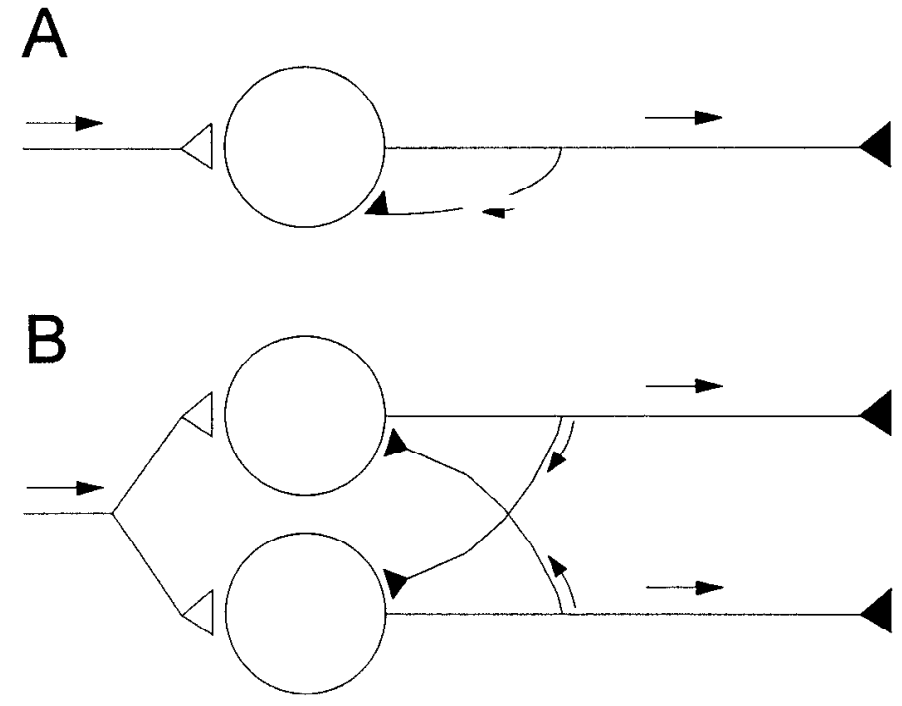

Figure 12. Proposed functional equivalence of autapses and local recurrent synapses. Arrows indicate flow of information; GABA terminals are shown as solid triangles, while excitatory inputs are shown as open triangles. $A$, In culture, medium-spiny neurons (one is shown), which would normally receive descending excitatory input form GABA autapses. $B$. In the intact $n A c c$, neighboring medium-spiny neurons receive similar descending input die to the topographic organization of projections to the nAcc and send recurrent collaterals to nearby mediumspiny neurons. Since excitatory synaptic inputs would activate both cells simultaneously, the two-cell configuration should be functionally similar to the autaptic configuration. Thus, GABA autapses in culture may model in vivo interactions between neighboring medium-spiny neurons.

line inhibits recurrent PSPs and significantly improves the highfrequency response, while agents strengthening recurrent PSPs such as benzodiazepines have the opposite effect. As reported in the nAcc slice (Uchimura and North, 1991), baclofen causes a direct hyperpolarization. The consequence is that larger depolarizing currents are needed to bring nAcc cells to threshold. $\mathrm{GABA}_{\mathrm{B}}$ receptors also mediate a more prominent presynaptic inhibition in the nAcc (Uchimura and North, 1991), as we have found for autaptic connections, leading to an enhanced response to suprathreshold stimulation. If one assumes that the sub- or near-threshold stimulation, such as that induced by random or nonsynchronized synaptic input, is noise and that suprathreshold stimulation constitutes signal, then baclofen improves the signal-to-noise ratio.

An increase in the signal-to-noise ratio could account for the behavioral changes associated with local injection of baclofen in the nAcc. Several groups have reported that baclofen inhibits spontaneous as well as dopamine-induced locomotion, which would be consistent with an increase in nAcc output (Kerwin et al., 1979; Plaznik et al., 1990; Stefanski et al., 1990; Wong et al., 1991). However, the previous reports of the cellular effects of baclofen predict that baclofen should decrease nAcc output if it directly hyperpolarizes nAcc cells and inhibits glutamatemediated synaptic potentials (Uchimura and North, 1991). Baclofen has also been found to increase the release of dopamine (Kovalev and Hetey, 1987), a transmitter believed to have a potent inhibitory effect on $\mathrm{nAcc}$ output. We suggest that these effects of baclofen may serve mainly to suppress synaptic noise in the $n A c c$ and it is the effect of baclofen on GABA synapses between medium-spiny neurons that is responsible for the increased output of the nAcc. 
Similar to baclofen, bicuculline also increases the signal-tonoise ratio; however, it has no effect on subthreshold stimulation (i.e., noise) and improves the signal response only to moderate stimulation. With strong stimulation, cells often burst and then go into depolarization block, while during baclofen, cells continue firing at high frequency even with strong depolarization. Several factors may contribute to the difference between baclofen and bicuculline: (1) baclofen, in addition to its presynaptic action, also hyperpolarizes cells, which would reduce the tendency of cells to go into depolarization inactivation; (2) the large depolarization that leads to depolarization inactivation after removal of autaptic inhibition may be mediated by an inward $\mathrm{Ca}^{2+}$ current; baclofen may inhibit this current as it does in other brain areas (e.g., Dolphin and Scott, 1987; Sah, 1990; Bindokas and Ishida, 1991; Marchetti et al., 1991; Tatebayashi and Ogata, 1992); (3) an excitatory cotransmitter (e.g., substance P) coreleased with GABA would no longer be opposed during bicuculline inhibition of GABA action, while baclofen in its presynaptic action would inhibit the release of both transmitter and cotransmitter. At present, the relative importance of the latter two factors in the generation of the large depolarization is unknown. Nevertheless, depolarization inactivation of $\mathrm{nAcc}$ cells observed during bicuculline may provide another explanation for why local infusion of hicuculline in the $\mathrm{nAcc}$, as well as picrotoxin, leads to an increase in the locomotor activityan indication of decreased nAcc output (Plaznik et al., 1990; Wong et al., 1991). There are, however, other possibilities, one of which is that bicuculline removes tonic GABA inhibition of DA terminals leading to an increase in DA release, which in turn inhibits nAcc output.

The benzodiazepine flurazepam and the GABA uptake blocker nipecotic acid each enhance autaptic PSPs. This should dampen cell responses to suprathreshold input. In some cells, nipecotic acid also increases spike threshold. If the signal-to-noise ratio is considered, flurazepam decreases the ratio, while nipecotic acid has little or no effect, as it decreases both signal and noise. Since behavioral studies with local infusion of these drugs have yet to be done, it is not clear how important their effects on intrinsic GABA synapses are in the observed behavioral changes. Nevertheless, the differential effects of the several GABA drugs discussed here point to the importance of intrinsic GABA synapses in regulating the signal-to-noise ratio in the nAcc response to excitatory afferent inputs.

In summary, we find that most nAcc medium-spiny neurons in culture form GABA autapses. Although their existence in vivo has not been convincingly demonstrated, GABA autapses in culture provide a simple system to examine nAcc GABA synapses formed by local axon collaterals of medium-spiny neurons. Our results - which may generalize to intrinsic nAcc GABA synapses - suggest a substrate for the action of neurotransmitters or drugs that dynamically modulate the input-output operations of the nAcc. Aberrant activity, either intrinsic to the synapses or due to aberrant modulation by other transmitters, may change the responses of $\mathbf{n A c c}$ cclls to their inputs, and thus contribute to the diseases thought to be due to disordered inputs into the nAcc. Moreover, drugs acting at these synapses may prove effective in ameliorating disordered inputs putatively involved in disorders such as schizophrenia.

\section{References}

Austin MC, Kalivas PW (1989) Blockade of enkephalinergic and GABAergic mediated locomotion in the nucleus accumbens by muscimol in the ventral pallidum. Jpn J Pharmacol 50:487-490.
Baughman RW, Huettner JE, Jones KA, Khan AA (1991) Cell culture of neocortex and basal forebrain from postnatal rats. In: Culturing nerve cells (Banker G, Goslin K, eds), pp 227-249. Cambridge, MA: MIT Press.

Bekkers JM, Stevens CF (1991) Excitatory and inhibitory autaptic currents in isolated hippocampal neurons maintained in cell culture. Proc Natl Acad Sci USA 88:7834-7838.

Bindokas VP, Ishida AT (1991) (-)-Baclofen and gamma-aminobutyric acid inhibit calcium currents in isolated retinal ganglion cells. Proc Natl Acad Sci USA 88:10759-10763.

Bishop GA, Chang HT, Kitai ST (1982) Morphological and physiological properties of neostriatal neurons: an intracellular horseradish peroxidase study in the rat. Neuroscience 7:179-191.

Bloom SR, Edwards AV, Garrett JR (1987) Effects of stimulating the sympathetic innervation in bursts on submandibular vascular and secretory function in cats. J Physiol (Lond) 393:91-106.

Bolam JP, Powell JF, Wu JY, Smith AD (1985) Glutamate decarboxylase-immunoreactive structures in the rat neostriatum: a correlated light and electron microscopic study including a combination of Golgi impregnation with immunocytochemistry. J Comp Neurol 237:1-20

Calabresi P, Mercuri NB, De Murtas M, Bernardi G (1991) Involvement of GABA systems in feedback regulation of glutamate- and GABA-mediated synaptic potentials in rat neostriatum. J Physiol (Lond) 440:581-599.

Campbell K, Kalén P, Lundberg C, Wictorin K, Rosengren E, Björklund A (1993). Extracellular gamma-aminobutyric acid levels in the rat caudate-putamen: monitoring the neuronal and glial contribution by intracerebral microdialysis. Brain Res 614:241-250.

Carlsson M, Carlsson A (1990) Interactions between glutamatergic and monoaminergic systems within the basal ganglia-implications for schizophrenia and Parkinson's disease. Trends Neurosci 13:272276.

Caruncho HJ, Puia G, Slobodyansky E, Pinto da Silva P, Costa E (1993) Freeze-fracture immunocytochemical study of the expression of native and recombinant $\mathrm{GABA}_{\mathrm{A}}$ receptors. Brain Res 603:234-242.

Cepeda C, Walsh JP, Hull CD, Howard SG, Buchwald NA, Levine MS (1989) Dye-coupling in the neostriatum of the rat: I. Modulation by dopamine-depleting lesions. Synapse 4:229-237.

Chang HT, Kitai ST (1985) Projection neurons of the nucleus accumbens: an intracellular labeling study. Brain Res 347:112-116.

Chang HT, Kitai ST (1986) Intracellular recordings from rat nucleus accumbens neurons in vitro. Brain Res 366:392-396.

Church J (1992) A change from $\mathrm{HCO}_{3}{ }^{-}-\mathrm{CO}_{2}{ }^{-}$to HEPES-buffered medium modifies membrane properties of rat CAl pyramidal neurones in vitro. I Physiol (Lond) 455:51-71.

Davies CH, Davies SN, Collingridge GL (1990) Paired-pulse depression of monosynaptic GABA-mediated inhibitory postsynaptic responses in rat hippocampus. J Physiol (Lond) 424:513-531.

Dolphin AC, Scott RH (1987) Calcium channel currents and their inhibition by $(-)$-baclofen in rat sensory neurones: modulation by guanine nucleotides. J Physiol (Lond) 386:1-17.

Dubinsky JM (1989) Development of inhibitory synapses among striatal neurons in vitro. J Neurosci 9:3955-3965.

Frosch MP, Dichter MA (1992) Non-uniform distribution of GABA activated chloride channels in cultured cortical neurons. Neurosci Lett 138:59-62.

Gerfen CR (1988) Synaptic organization of the striatum. J Electron Microsc Tech 10:265-281.

Gonon FG (1988) Nonlinear relationship between impulse flow and dopamine released by rat midbrain dopaminergic neurons as studied by in vivo electrochemistry. Neuroscience 24:19-28.

Groves PM (1983) A theory of the functional organization of the neostriatum and the neostriatal control of voluntary movement. Brain Res Rev 5:109-132.

Higashi H, Inanaga K, Nishi S, Uchimura N (1989) Enhancement of dopamine actions on rat nucleus accumbens neurones in vitro after methamphetamine pre-treatment. J Physiol (Lond) 408:587-603.

Isaacson JS, Solís JM, Nicoll RA (1993) Local and diffuse synaptic actions of GABA in the hippocampus. Neuron 10:165-175.

Johnson SW, Mercuri NB, North RA (1992) 5-Hydroxytryptamine ${ }_{13}$ receptors block the $\mathrm{GABA}_{\mathrm{B}}$ synaptic potential in rat dopamine neurons. J Neurosci 12:2000-2006.

Kafetzopoulos E (1988) GABAergic mechanisms mediating rotational behavior in rats: differences between dorsal and ventral striatum. Pharmacol Biochem Behav 29:457-460. 
Katayama Y, Miyazaki S, Tsubokawa T (1981) Electrophysiological evidence favoring intracaudate axon collaterals of GABAergic caudate output neurons in the cat. Brain Res 216:180-186.

Kawaguchi Y, Wilson CJ, Emson PC (1989) Intracellular recording of identified neostriatal patch and matrix spiny cells in a slice preparation preserving cortical inputs. J Neurophysiol 62:1052-1068.

Kawaguchi Y, Wilson CJ, Emson PC (1990) Projections subtypes of rat neostriatal matrix cells revealed by intracellular injection of biocytin. J Neurosci 10:3421-3438.

Kerwin RW, Carter C, Pycock C (1979) A comparison of $l$-and $d$-baclofen on dopamine dependent behaviour in the rat. Neuropharmacology 18:655-659.

Kito S, Shimoyama M, Arakawa R (1986) Effects of neurotransmitters or drugs on the in vivo release of dopamine and its metabolites. Jpn J Pharmacol 40:57-67.

Kovalev GI, Hetey L (1987) Regulation of ${ }^{3} \mathrm{H}$-dopamine release by presynaptic GABA and glutamate heteroreceptors in the synaptosomes of the rat nuclcus accumbens. Biull Eksp Biol Med 103:7578 .

Kuruvilla A, Uretsky NJ (1984) Effect of intrastriatal administration of cholinergic and GABAergic agonists on apomorphine-induced circling. Psychopharmacology (Berlin) 84:42-47.

Lacaille JC, Mueller AL, Kunkel DD, Schwartzkroin PA (1987) Local circuit interactions between oriens/alveus interneurons and CA 1 pyramidal cells in hippocampal slices: electrophysiology and morphology. J Neurosci 7:1979-1993.

Lighthall JW, Kitai ST (1983) A short duration GABAergic inhibition in identified neostriatal medium spiny neurons: in vitro slice study. Brain Res Bull 11:103-110.

Lundberg JM, Rudehill A, Sollevi A, Theodorsson-Norheim E, Hamberger B (1986) Frequency- and reserpine-dependent chemical coding of sympathetic transmission: differential release of noradrenaline and neuropeptide $Y$ from pig spleen. Neurosci Lett 63:96-100.

Marchetti C, Carignani C, Robello M (1991) Voltage-dependent calcium currents in dissociated granule cells from rat cerebellum. Neuroscience 43:121-133.

Miles R (1990) Variation in strength of inhibitory synapses in the CA3 region of guinea-pig hippocampus in vitro. J Physiol (Lond) 431:659676.

Morgenstern R, Mende T, Gold R, Lemme P, Oelssner W (1984) Drug-induced modulation of locomotor hyperactivity induced by picrotoxin in nucleus accumbens. Pharmacol Biochem Behav 21:501506.

Nisenbaum ES, Berger TW, Grace AA (1992) Presynaptic modulation by $\mathrm{GABA}_{0}$ receptors of glutamatergic excitation and GABAergic inhibition of neostriatal neurons. J Neurophysiol 67:477-481.

O'Donnell P, Grace AA (1993) Physiological and morphological properties of accumbens core and shell neurons recorded in vitro. Synapse 13:135-160.

Oxford GS, Wagoner PK (1989) The inactivating $\mathrm{K}^{+}$current in GH3 pituitary cells and its modification by chemical reagents. J Physiol (Lond) 410:587-612.

Park MR, Lighthall JW, Kitai ST (1980) Recurrent inhibition in the rat neostriatum. Brain Res 194:359-369.

Pasik P, Pasik T, Holstein GR, Hamori J (1988) GABAergic elements in the neuronal circuits of the monkey neostriatum: a light and electron microscopic immunocytochemical study. J Comp Neurol 270: $157-170$.

Paxinos G, Tork I, Tecott LH, Valentino KL (1991) Atlas of the developing rat brain. San Diego: Academic.

Pennartz CM, Kitai ST (1991) Hippocampal inputs to identified neurons in an in vitro slice preparation of the rat nucleus accumbens: evidence for feed-forward inhibition. J Neurosci 11:2838-2847.

Penny GR, Wilson CJ, Kitai ST (1988) Relationship of the axonal and dendritic geometry of spiny projection neurons to the compartmental organization of the neostriatum. J Comp Neurol 269:275289.

Pin JP, Bockaert J (1989) Two distinct mechanisms, differentially affected by excitatory amino acids, trigger GABA release from fetal mouse striatal neurons in primary culture. J Neurosci 9:648-656.

Plaznik A, Stefanski R, Kostowski W (1990) GABAergic mechanisms in the nucleus accumbens septi regulating rat motor activity: the effect of chronic treatment with desipramine. Pharmacol Biochem Behav 36:501-506.

Preston RJ, Bishop GA, Kitai ST (1980) Medium spiny neuron pro- jection from the rat striatum: an intracellular horseradish peroxidase study. Brain Res 183:253-263.

Rayport S, Sulzer D, Shi W-X, Sawasdikosol S, Monac J, Batson D, Rajendran G (1992) Identified postnatal mesolimbic dopamine neurons in cell culture: morphology and electrophysiology. J Neurosci 12:4264-4280.

Regehr W, Kehoe JS, Ascher P, Armstrong C (1993) Synaptically triggered action potentials in dendrites. Neuron 11:145-151.

Reichling DB, MacDermott AB (1991) Lanthanum actions on excitatory amino acid-gated currents and voltage-gated calcium currents in rat dorsal horn neurons. J Physiol (Lond) 441:199-218.

Sah DWY (1990) Neurotransmitter modulation of calcium current in rat spinal cord neurons. J Neurosci 10:136-141.

Schultz W, Apicella P, Scarnati E, Ljungberg T (1992) Neuronal activity in monkey ventral striatum related to the expectation of reward. J Neurosci 12:4595-4610.

Segal MM (1991) Epileptiform activity in microcultures containing one excitatory hippocampal neuron. J Neurophysiol 65:761-770.

Segal MM, Furshpan EJ (1990) Epileptiform activity in microcultures containing small numbers of hippocampal neurons. J Neurophysiol 64:1390-1399.

Seack SR, Pickel VM (1992) Prefrontal cortical efferents in the rat synapse on unlabeled neuronal targets of catecholamine terminals in the nucleus accumbens septi and on dopamine neurons in the ventral tegmental area. J Comp Neurol 320:145-160.

Shi W-X, Rayport S (1992) Modulation of nucleus accumbens neurons by their local axon collaterals. Soc Neurosci Abstr 18:4.

Smith AD, Bolam JP (1990) The neural network of the basal ganglia as revealed by the study of synaptic connections of identified neurones. Trends Neurosci 13:259-265.

Somogyi P, Takagi II, Richards JG, Mohler II (1989) Subcellular distribution of benzodiazepine/ $\mathrm{GABA}_{\mathrm{A}}$ receptors in the cerebellum of rat, cat, and monkey using monoclonal antibodies. J Neurosci 9:2197-2209.

Staley KJ, Otis TS, Mody I (1992) Membrane properties of dentate gyrus granule cells: comparison of sharp microelectrode and wholecell recordings. J Neurophysiol 67:1346-1358.

Stefanski P, Plaznik A, Palejko W, Kostowski W (1990) Myorelaxant effect of baclofen injected to the nucleus accumbens septi. J Neura Transm [Park Dis Dement Sect] 2:179-191.

Suaud-Chagny MF, Chergui K, Chouvet G, Gonon F (1992) Relationship between dopamine release in the rat nucleus accumbens and the discharge activity of dopaminergic neurons during local in vivo application of amino acids in the ventral tegmental area. Neuroscience 49:63-72.

Sugita S, Johnson SW, North RA (1992) Synaptic inputs to GABA and $\mathrm{GABA}_{\mathrm{B}}$ receptors originate from discrete afferent neurons. Neurosci Lett 134:207-211.

Tatebayashi $H$, Ogata $N$ (1992) Kinetic analysis of the $\mathrm{GABA}_{\mathrm{B}}$-mediated inhibition of the high-threshold $\mathrm{Ca}^{2}+$ current in cultured rat sensory neurones. J Physiol (Lond) 447:391-407.

Totterdell S, Smith AD (1989) Convergence of hippocampal and dopaminergic input onto identified neurons in the nucleus accumbens of the rat. J Chem Neuroanat 2:285-298.

Uchimura N, North RA (1991) Baclofen and adenosine inhibit synaptic potentials mediated by gamma-aminobutyric acid and glutamate release in rat nucleus accumbens. J Pharmacol Exp Ther 258: 663-668.

Uchimura N, Higashi H, Nishi S (1989) Membrane properties and synaptic responses of the guinea pig nucleus accumbens neurons in vitro. J Neurophysiol 61:769-779.

van der Loos H, Glaser EM (1972) Autapses in neocortex cerebri: synapses between a pyramidal cell's axon and its own dendrites. Brain Res 48:355-360.

Ventimiglia R, Grierson JP, Gallombardo P, Sweetman PM, Tallman JF, Geller HM (1990) Cultured rat neurons and astrocytes express immunologically related epitopes of the $\mathrm{GABA}_{\mathrm{A}}$ /benzodiazepine receptor. Neurosci Lett 115:131-136.

Whim MD, Lloyd PE (1989) Frequency-dependent release of peptide cotransmitters from identified cholinergic motor neurons in Aplysia. Proc Natl Acad Sci USA 86:9034-9038.

White RL, Gardner D (1981) Self-inhibition alters firing patterus of neurons in Aplysia buccal ganglia. Brain Res 209:77-93.

Wong LS, Eshel G, Dreher J, Ong J, Jackson DM (1991) Role of 
dopamine and GABA in the control of motor activity elicited from the rat nucleus accumbens. Pharmacol Biochem Behav 38:829-835.

Worms P, Chambon JP, Biziere K (1987) Behavioural evidence for a selective GABA-A antagonistic activity of SR 95103 and SR 42641 after intrastriatal injection in mice. Eur J Pharmacol 138:343-350.
Zetterström T, Fillenz M (1990) Local administration of flurazepam has different effects on dopamine release in striatum and nucleus accumbens: a microdialysis study. Neuropharmacology 29:129134. 